\title{
Improved Learning Outcomes Of Social Sciences Lessons Through Google Meet Assisted Powerpoint Media
}

\author{
Tri Utami \\ SDN Randugunting 7 Kota Tegal \\ triutami0093@gmail.com
}

\section{Article History}

received $3 / 12 / 2020$

\begin{abstract}
This research is a classroom action research (CAR) which aims to improve student learning outcomes in social studies subject matter through the use of the Google Meet application with the help of PowerPoint learning media. The sample in this study amounted to 12 students. The research method used is Classroom Action Research (CAR) in two cycles consisting of two meetings in each cycle. The stages of each cycle are planning, implementation, observation and reflection. In the first cycle, the students who completed the post test were $66.67 \%$, and in the second cycle $91.67 \%$. From this analysis, it can be seen from the increase in student learning outcomes in cycle I to cycle II. It can be concluded that the use of the google meet application with the help of powerpoint learning media can improve student learning outcomes, especially in Social Studies class VI SDN Randugunting 7 Tegal City.
\end{abstract}

Keywords: learning outcomes, powerpoint media, social science lessons

\begin{abstract}
Abstrak
Penelitian ini merupakan peneliatian tindakan kelas (PTK) yang bertujuan untuk meningkatkan hasil belajar peserta didik pada muatan pelajaran IPS melalui penggunaan aplikasi google meet berbanu media pembelajaran powerpoint. Sampel pada penelitian ini berjumlah 12 peserta didik. Metode penelitian yang dilakukan adalah Penelitian Tindakan Kelas (PTK) sebanyak dua siklus yang terdiri dari dua pertemuan pada setiap siklus. Tahapan setiap siklusnya adalah perencanaan, pelaksanaan, observasi dan refleksi. Pada siklus I peserta didik yang tuntas setelah melaksanakan post test sebesar $66.67 \%$, dan pada siklus II sebesar $91.67 \%$. Dari analisis tersebut terlihat dari peningkatan hasil belajar peserta didik siklus I hingga siklus II. Hal ini dapat disimpulkan bahwa penggunaan aplikasi google meet berbantu media pembelajaran powerpoint dapat meningkatkan hasil belajar peserta didik khususnya mupel IPS Kelas VI SDN Randugunting 7 Kota Tegal.
\end{abstract}

Kata kunci: hasil belajar, powerpoint media, IPS 


\section{PENDAHULUAN}

Indonesia merupakan salah satu negara di dunia yang tengah dihadapkan pada pandemi Covid-19. Dampak dari pandemi Covid-19 telah mengubah tatanan di berbagai aspek kehidupan manusia, diantaranya aspek sosial, budaya, politik, ekonomi, dan khususnya pendidikan. Berdasarkan pada Surat Edaran (SE) yang diterbitkan oleh pemerintah pada tanggal 18 Maret 2020 bahwa semua kegiatan baik di luar maupun di dalam ruangan maka sementara waktu kegiatan tersebut ditunda untuk mengurangi penyebaran virus COVID-19 tidak terkecuali bidang pendidikan. Hal tersebut diperkuat dengan dikeluarkannya surat edaran nomor 4 tahun 2020 tentang pelaksanaan Kebijakan Pendidikan dimasa darurat penyebaran COVID-19 pada tanggal 24 Maret 2020 oleh Menteri Pendidikan dan Kebudayaan Republik Indonesia. Surat edaran tersebut menjelaskan bahwa proses belajar mengajar dilaksanakan di rumah melalui pembelajaran daring atau virtual atau pembelajaran jarak jauh (PJJ). Belajar dari rumah dapat difokuskan pada pendidikan kecakapan hidup antara lain mengenai pandemi COVID-19. (Dewi 2020).

Pembelajaran jarak jauh merupakan pembelajaran yang dilakukan dengan cara pendidik, peserta didik, dan bahan ajar berada di tempat yang terpisah oleh ruang dan disatukan atau dihubungkan dengan bantuan alat teknologi komunikasi (Iskenderoglu et al., 2012). Pembelajaran daring sangat berbeda dengan pembelajaran klasikal bertatap muka. Pada pembelajaran daring guru dituntut menguasai pemanfaatan teknologi agar bisa menyampaikan materi pembelajaran kepada peserta didik dengan baik sehingga tujuan pembelajaran dapat tercapai. Namun, pada kenyataannya pembelajaran daring ternyata menimbulkan sebuah permasalahan baru di dunia pendidikan, hal ini karena ketidaksiapan guru dan peserta didik dalam melaksanakan pembelajaran daring yang banyak menuntut pemanfaatan teknologi untuk menunjang proses pembelajaran. Akibatnya, tujuan pembelajaran tidak tercapai ditandai dengan nilai peserta didik yang masih belum mencapai KKM pada sebagian besar muatan pelajaran.

Materi pada pelajaran IImu Pengetahuan Sosial (IPS) bukanlah materi yang mudah untuk difahami peserta didik. Hal ini dikarenakan minimnya dokumentasi video dan gambar-gambar tentang kegiatan sosial, fenomena sosial dan khususnya peristiwa sejarah membuat peserta didik sulit membayangkan dan memahami kejadian sosial apa saja yang ada di sekitarnya, sehingga rasa ketertarikan untuk mempelajari mata pelajaran IPS pun menurun. Gunawan (2011:36) mengemukakan bahwa pengertian pembelajaran IPS di sekolah dasar adalah suatu bahan kajian yang terpadu yang merupakan penyederhanaan, adaptasi, seleksi, dan modifikasi yang diorganisasikan dari konsep-konsep dan keterampilan sejarah, geografi, sosiologi, antropologi, dan ekonomi.

Berdasarkan hasil pengamatan peneliti khususnya pada muatan pelajaran IPS Kelas VI di SDN Randugunting 7 Kota Tegal terjadi kesenjangan antara tujuan pembelajaran dan capaian hasil belajar. Hal ini menunjukkan bahwa guru menyajikan pembelajaran daring secara monoton, nampak pada RPP yang belum dapat dikategorikan baik, sumber belajar yang terbatas, tidak adanya media pembelajaran yang menarik, dan belum adanya pemanfaatan teknologi kekinian yang bisa mempermudah pembelajaran daring. Hal tersebut menjadikan peserta didik tidak tertarik pada pembelajaran daring sehingga hasil belajar khususnya pada muatan pelajaran IPS materi peristiwa poklamasi kemerdekaan Indonesia belum mencapai kategori ketuntasan klasikal. Menurut (Trianto,2010:241) ketuntasan klasikal dapat tercapat jika $>85 \%$ peserta didik telah mencapai nilai KKM yang ditetapkan. Berdasarkan pada data hasil pengamatan peneliti, rata-rata nilai peserta didik kelas VI pada muatan pelajaran IPS materi peristiwa proklamasi kemerdekaan Indonesia yaitu 57.50. prosentase ketuntasan belajar peserta didik pada materi tersebut yakni $33.33 \%$ atau hanya 4 peserta didik dari 12 jumlah peserta didik yang telah memenuhi standar nilai KKM. 
Berdasarkan pada permasalahan di atas, maka upaya peningkatan hasil belajar IPS merupakan suatu kebutuhan yang sangat mendesak untuk dilakukan. Guru hendaknya mengubah pola pembelajaran daring yang monoton dengan pembelajaran yang lebih bermakna bagi peserta didik. Guru perlu menerapkan pemanfaatan aplikasi dan media pemebelajaran yang tepat sehingga peserta didik lebih semangat dalam belajar dan capaian hasil belajar lebih optimal.

Salah satu aplikasi online yang banyak digunakan pada saat pembelajaran daring adalah Google Meet. Google meet adalah layanan konferensi video/meeting online yang dikembangkan oleh google. Banyak sekali kelebihan dari apikasi tersebut yang dapat digunakan pada saat pembelajaran daring. Aplikasi ini tidak memerlukan akses internet yang tinggi sehingga mudah digunakan dimana saja dan kapan saja. Setiap peserta didik yang memiliki akun google dapat dengan mudah berpartisipasi dalam pembelajaran online melalui google meet (Arifin, 2020). Namun, penggunaan aplikasi google meet tidak berjalan optimal dalam pembelajaran daring jika disertai penampilan media pembelajaran yang tepat.

Media adalah wadah dari pesan yang oleh sumbernya ingin diteruskan kepada sasaran atau penerima pesan tersebut (Kustandi, 2013:07). Sebagai penyaji dan penyalur pesan, media belajar dalam hal-hal tertentu bisa mewakili guru menyajiakan informasi belajar kepada peserta didik. Jika program media itu didesain dan dikembangkan secara baik, maka fungsi itu akan dapat diperankan oleh media meskipun tanpa keberadaan guru. Ariastuti (2017) bahwa media pembelajaran memiliki fungsi utama untuk meningkatkan motivasi peserta didik dan mencegah kebosanan peserta didik dalam belajar. Salah satu media yang dapat digunakan untuk menarik perhatian peserta didik dalam proses pembelajaran daring ialah media powerpoint. Powerpoint adalah alat bantu presentasi, biasanya digunakan untuk menjelaskan suatu hal yang dirangkum dan dikemas dalam slide powerpoint. Sehingga pembaca dapat lebih mudah memahami penjelasan kita melalui visualisasi yang terangkum di dalam slide. Powerpoint merupakan program untuk membantu mempresentasikan dan menampilkan presentasi dalam bentuk tulisan,gambar, grafik, objek, clipart, movie, suara, atau video yang dimainkan pada saat presentasi (Purnomo, 2010). Keunggulan powerpoint antara lain: 1) praktis, dapat dipergunakan untuk semua ukuran kelas; 2) memberikan kemungkinan tatap muka dan mengamati respons peserta didik; 3) memiliki variasi teknik penyajian yang menarik dan tidak membosankan; 4) dapat menyajikan berbagai kombinasi clipart, picture, warna animasi dan suara, sehingga membuat peserta didik lebih tertari; 5) dapat dipergunakan berulang-ulang. berikut:

Berdasarkan uraian latar belakang di atas dapat dirumuskan masalah sebagai

1. Apakah melalui google meet berbantu media powerpoint dapat meningkatkan hasil belajar muatan pelajaran IPS materi peristiwa proklamasi kemerdekaan Indonesia pada peserta didik kelas VI SDN Randugunting 7 Kota Tegal?

2. Bagaimana meningkatkan hasil belajar peserta didik melalui google meet berbantu media powerpoint dapat meningkatkan hasil belajar muatan pelajaran IPS materi peristiwa proklamasi kemerdekaan Indonesia pada peserta didik kelas VI SDN Randugunting 7 Kota Tegal?

Dari uraian latar belakang dan rumusan masalah di atas penelitian tindakan kelas ini secara umum memiliki tujuan untuk mengatasi masalah yang terjadi pada pembelajaran supaya pembelajaran yang berlangsung mendapatkan hasil yang lebih baik sehingga prestasi belajar siswa meningkat. Sedangkan secara khusus tujuan dari penelitian ini adalah sebagai berikut:

1. Untuk mengetahui apakah melalui google meet berbantu media powerpoint dapat meningkatkan muatan pelajaran IPS materi peristiwa proklamasi kemerdekaan Indonesia pada peserta didik kelas VI SDN Randugunting 7 Kota Tegal Tahun Pelajaran 2020/2021. 
2. Untuk mengetahui bagaimana penerapan google meet berbantu media powerpoint dapat meningkatkan muatan pelajaran IPS materi peristiwa proklamasi kemerdekaan Indonesia pada peserta didik kelas VI SDN Randugunting 7 Kota Tegal Tahun Pelajaran 2020/2021.

\section{METODE}

Metode yang digunakan dalam penelitian ini adalah penelitian tindakan kelas yang dilaksanakan dalam dua siklus yang mengacu pada model Kemmis \& Mc Taggart (dalam Arikunto, 2013:138-140). Penelitian ini dilaksanakan melalui pembelajaran daring (dalam jaringan). Masing-masing siklus terdiri dari empat tahap yaitu (1) perencanaan, (2) pelaksanaan, (3) pengamatan, dan (4) refleksi. Pelaksanaan penelitian di SDN Randugunting 7 Kota Tegal dengan subjek peserta didik kelas VI tahun ajaran 2020/2021 yang berjumlah 12 peserta didik terdiri dari 8 peserta didik laki-laki dan 4 peserta didik perempuan. Teknik dan alat pengumpulan data yang digunakan adalah menggunakan teknik observasi, tes, dan dokumentasi. Analisis data kuantitatif digunakan untuk menentukan peningkatan keterampilan membaca pemahaman peserta didik sebagai pengaruh dari setiap tindakan yang dilakukan oleh peneliti. Indikator keberhasilan penelitian yaitu ketuntasan minimal peserta didik pada mupel IPS materi peristiwa proklamasi kemerdekaan Indonesia menggunakan media pembelajaran powerpoint mencapai ketuntasan klasikal lebih dari $85 \%$.

\section{HASIL DAN PEMBAHASAN}

Penelitian Tindakan Kelas ini dilakukan melalui 2 siklus yaitu siklus I dan siklus II yang mengacu pada model Kemmis \& Mc Taggart ada beberapa tahapan dalam penelitian ini, yaitu: (1) perencanaan, (2) pelaksanaan, (3) pengamatan, (4) refleksi yang dilakukan pada peserta didik SDN Randugunting 7 Kota Tegal.

Sebelum dilakukan tindakan siklus I peneliti melakukan pembelajaran pra siklus untuk mengetahui hasil belajar materi peristiwa proklamasi kemerdekaan Indonesia pada peserta didik kelas VI SDN Randugunting 7 Kota Tegal. Hasil yang diperoleh yaitu sebesar $16.67 \%$, atau hanya 2 dari 12 peserta didik yang memenuhi KKM ( $\geq 70)$ dan sebanyak 10 peserta didik belum mencapai batas nilai KKM. Rata-rata nilai pada tahapan pra siklus yaitu 47.08 dengan nilai tertinggi 85 dan nilai terendah 20. Data tersebut menunjukkan bahwa hasil belajar materi peristiwa proklamasi kemerdekaan Indonesia pada peserta didik kelas VI SDN Randugunting 7 masih sangat rendah. Fakta tersebut mendorong peneliti untuk meningkatkan hasil belajar materi peristiwa proklamasi kemerdekaan Indonesia pada peserta didik kelas VI SDN Randugunting 7 Kota Tegal.

Penelitian ini mengaplikasikan google meet berbantu media powerpoint dalam pembelajaran daring untuk meningkatkan hasil belajar IPS materi peristiwa proklamasi kemerdekaan Indonesia, sehingga hasil pembelajaran menjadi lebih optimal dan mencapai nilai ketuntasan 70 dan ketuntasan secara klasikal mencapai lebih dari 85\%. Langkah-langkah dalam pembelajaran melalui google meet berbantu media powerpoint seperti yang disebutkan oleh (Julianto, 2011:22) meliputi : (1) penyajian materi pelajaran, (2) pembentukan kelompok, (3) diskusi, (4) publikasi, (5) pemberian penghargaan, (6) evaluasi dan (7) kesimpulan. Sebelum diberi tindakan guru menetapkan kompetensi dasar yang digunakan sebagai materi pada pengimpelemntasian google meet berbantu media powerpoint. Kemudian disusun rancangan pembelajaran berupa Rencana Pelaksanaan Pembelajaran (RPP) berdasrakan kurikulum 2013. Pembuatan RPP dilakukan secara mandiri dan ditentukan KKM yaitu 70. Tidak lupa peneliti juga mempersiapkan penggunaan google meet pada siswa dan menyiapkan media pembelajaran berupa powerpoint.

Setelah dilaksanakan pembelajaran daring melalui google meet berbantu media pembelajaran powerpoint pada siklus I dan II hasil belajar peserta didik pada materi peristiwa proklamasi kemerdekaan Indonesia mengalami peningkatan. hal ini 
dipengaruhi beberapa faktor antara lain guru dan peserta didik terlibat komunikasi dua arah ketika pembelajaran daring melalui google meet, peserta didik lebih tertarik dan aktif saat pembelajaran berlangsung. Data hasil belajar peserta didik pada siklus I dan siklus II adalah sebagai berikut :

Tabel 1. Rekapitulasi Hasil Belajar Peserta didik Kelas VI

\begin{tabular}{lccc}
\hline \multicolumn{1}{c}{ Aspek } & Pra Siklus & Siklus I & Siklus II \\
\hline Nilai Rata-rata & 47.08 & 71.25 & 77.91 \\
Nilai tertinggi & 85 & 90 & 100 \\
Nilai terendah & 20 & 40 & 40 \\
Peserta didik yang Tuntas & 2 & 8 & 11 \\
Peserta didik yang belum Tuntas & 10 & 4 & 1 \\
Prosentase peserta didik Tuntas & $16.67 \%$ & $66.67 \%$ & $91.67 \%$ \\
Prosentase peserta didik belum Tuntas & $83.33 \%$ & $33.33 \%$ & $8.03 \%$ \\
\hline
\end{tabular}

Dari tabel di atas dapat dilihat bahwa pada pra siklus masih banyak peserta didik yang belum memenuhi batas KKM muatan pelajaran IPS pada materi peristiwa proklamasi kemerdekaan Indonesia dan prosentasi ketuntasan secara klasikal belum mencapai $85 \%$. Dari data yang diperoleh pada pra siklus, peserta didik yang telah mencapai KKM sebanyak $16.67 \%$ atau hanya 2 peserta didik dan $83.33 \%$ atau 10 peserta didik belum mencapai KKM. Nilai rata-rata kelas dari 12 peserta didik adalah 47.08, nilai tertinggi yaitu 85 dan nilai terendah 20. Berdasarkan hal ini peneliti mencoba untuk melakukan tindakan perbaikan pembelajaran daring melalui google meet berbantu media pembelajaran Powerpoint untuk meningkatkan hasil belajar IPS materi peristiwa proklamasi kemerdekaan pada peserta didik kelas VI.

Pada siklus I pembelajaran daring telah dilakukan melalui google meet berbantu media pembelajaran Powerpoint dan bisa dilihat bahwa terjadi peningkatan nilai IPS materi peristiwa kemerdekaan Indonesia peserta didik kelas VI. Nilai rata-rata peserta didik menunjukkan bahwa hasil Pembelajaran IPS materi peristiwa proklamasi kemerdekaan Indonesia cukup memuaskan karena sebanyak $66.67 \%$ atau 8 peserta didik sudah mencapai nilai KKM dan sebanyak $33.33 \%$ atau 4 peserta didik belum mencapai KKM. Nilai rata-rata kelas dari 12 peserta didik adalah 71.25 , nilai tertinggi yaitu 90 dan nilai terendah 40 . Tetapi ternyata indikator kerja atau ketuntasan secara klasikal belum mencapai $85 \%$ sehingga penelitian harus dilanjutkan ke siklus berikutnya.

Berdasarkan pada refleksi siklus I dapat terlihat bahwa ketuntasan klasikal belum mencapai $85 \%$, maka penelitian dilanjutkan pada siklus II dengan tetap menerapkan pembelajaran daring melalui google meet berbantu media powerpoint. Data yang dihasilkan pada siklus II mengalami peningkatan ketuntasan hasil belajar dari siklus I, dapat terlihat dari tabel pada siklus I sebanyak 8 peserta didik dan pada siklus II terlihat 11 peserta didik yang telah mencapai ketuntasan hasil belajar. Sementara pencapaian nilai rata-rata kelas pada siklus I mencapai 71.25 dan pada siklus II meningkat menjadi 77.91. Pada pelaksanan siklus II peserta didik yang telah mencapai KKM sebanyak $91.67 \%$ atau 11 peserta didik dan $8.03 \%$ atau 1 peserta didik belum mencapai KKM. Nilai tertinggi pesera didik pada siklus II adalah 90 dan nilai terendah adalah 40 . Walaupun Pada siklus II masih ada peserta didik yang belum mencapai KKM tetapi dari 
data yang didapatkan sudah menunjukkan peningkatan dan sudah menunjukkan hasil yang termasuk sangat memuaskan, karena sudah mencapai indikator keberhasilan klasikal yang telah ditetapkan yaitu ketuntasan belajar peserta didik minimal $85 \%$.

Di bawah ini disajikan sebuah diagram peningkatan hasil pembelajaran IPS materi perisiwa proklamasi kemerdekaan Indonesia peserta didik kelas VI dari pra siklus, siklus I dan siklus II yang lebih jelas :

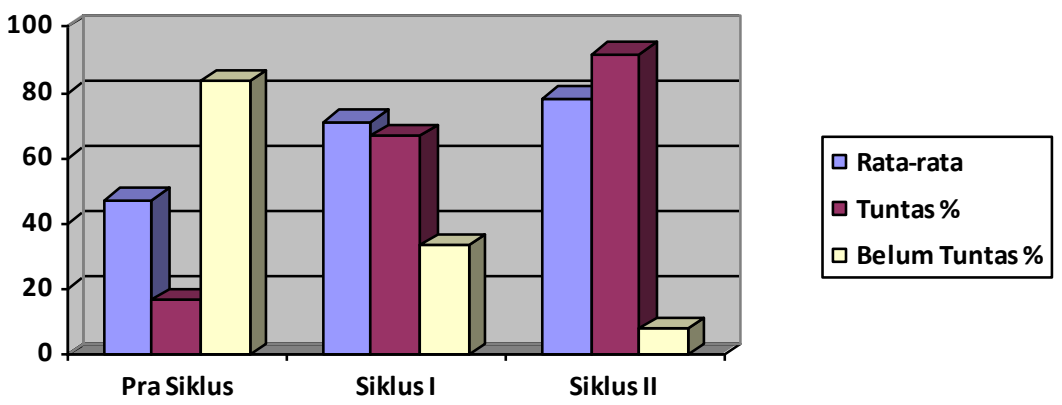

Gambar 1. Peingkatan Hasil belajar Peserta Didik Kelas VI

Berdasarkan data tersebut maka dapat diketahui bahwa pelaksanaan PTK dengan penerapan pembelajaran daring melalui google meet berbantu media pembelajaran powerpoint berhasil meningkatkan hasil belajar peserta didik pada muatan pelajaran IPS dalam materi peristiwa proklamasi kemerdekaan Indonesia. Penerapan pembelajaran daring melalui google meet berbantu media pembelajaran powerpoint tampak memberikan perubahan yang positif dalam kegiatan belajar mengajar. Dampak positif tersebut terlihat dari peserta didik yang aktif, semangat, dan fokus dalam mengikuti kegiatan belajar mengajar sehingga memberikan dampak peningkatan hasil belajar peserta didik. Berdasarkan data tersebut dapat diketahui bahwa penerapan pembelajaran melalui google meet berbantu media pembelajaran Powerpoint terbukti dapat meningkatkan hasil belajar peserta didik pada muatan IPS materi peristiwa proklamasi kemerdekaan Indonesia di kelas VI SDN Randugunting 7 Kecamatan Tegal Selatan Kota Tegal Tahun Pelajaran 2020/2021.

\section{SIMPULAN}

Berdasarkan hasil penelitian tindakan kelas yang dilakukan di SDN Randugunting 7 Kec. Tegal Selatan Kota Tegal Tahun Pelajaran 2020/2021, dapat disimpulkan bahwa penerapan pembelajaran melalui google meet berbantu media pembelajaran powerpoint dapat meningkatkan hasil belajar muatan pelajaran IPS dalam materi peristiwa proklamasi kemerdekaan Indonesia pada peserta didik kelas VI semester 1 SDN Randugunting 7 Kota Tegal. Hal ini dibuktikan dengan adanya peningkatan hasil belajar peserta didik pada siklus 1 yaitu terjadi peningkatan prosentase ketuntasan peserta didik sebesar 33,34\%. Berdasarkan kondisi pra siklus (awal) dari 12 peserta didik hanya 4 peserta didik (33.33\%) peserta didik yang memenuhi standar kriteria ketuntasan minimal dan 8 peserta didik (66.67\%) belum memnuhi standar kriteria ketuntasan minimal dengan perolehan nilai rata-rata 57.50, sedangkan data yang didapat pada siklus 1 yaitu dari 12 peserta didik sebanyak 8 peserta didik (66.67\%) sudah memenuhi standar kriteria ketuntasan minimal dan 4 peserta didik (33.33\%) belum memenuhi standar 
kriteria ketuntasan minimal dengan perolehan nilai rata-rata 71.25. Terjadi peningkatan prosentase ketuntasan dari siklus 1 ke siklus 2 sebesar $25 \%$. Hal ini dapat dilihat dari hasil belajar peserta didik yaitu dari 12 peserta didik sebanyak 11 peserta didik (91.67\%) sudah memenuhi standar kriteria ketuntasan minimal dan 1 peserta didik (8.03\%) belum memenuhi standar kriteria ketuntasan minimal dengan perolehan nilairata-rata 77.91. Maka dapat dikatakan bahwa Penelitian Tindakan Kelas ini dinyatakan berhasil karena indikator keberhasilan secara klasikal yaitu $\geq 85 \%$ sudah tercapai hal ini dibuktikan dengan adanya data hasil belajar peserta didik pada siklus 2 sebesar $91.67 \%$ dengan perolehan nilai rata-rata $77.91(91.677 \% \geq 85 \%)$. Maka siklus dihentikan atau dinyatakan berhenti pada siklus 2 karena Indikator Keberhasilan secara klasikal dan individual sudah terpenuhi atau tercapai.

\section{DAFTAR PUSTAKA}

Ariastuti, Anik. 2017. Peningkatan Minat Belajar Bahasa Inggris Peserta didik melalui Media Audio Visual. Jurnal Pendidikan Profesi Vol. 5 No. 2; 283-298. CV. Putra Sukses.

Arifin, Rudi Dian. 2020. Pengertian Google Meet, Fitur, Manfaat dan Cara menggunakan. Diakses dari https://dianisa.com/pengertian-google-meet/

Arikunto, dkk. 2007. Penelitian Tindakan Kelas. Jakarta : PT. Bumi Askara

Dewi, Wahyu Aji Fatma. 2020. "Dampak COVID-19 Terhadap Implementasi Pembelajaran Daring Di Sekolah Dasar." EDUKATIF : JURNAL ILMU PENDIDIKAN 2(1):55-61.

Gunawan, Rudi. 2013. Pendidikan IPS Filosofi, Konsep, dan Aplikasi. Bandung: Alfabeta

Kor, H., Aksoy, H., \& Erbay, H. (2014). Comparison of the proficiency Level of the Course Materials (animations, Videos, Simulation, E-Books) Used In Distance Education. Procedia - Social and Behavioral Sciences, 141.

Kustandi, Cecep., dan Sutjipto, Bambang. 2013. Media Pembelajaran: Manual dan Digital. Bogor: Ghalia Indonesia.

Purnomo, Catur Hadi, 2010, Presentasi Kreatif dengan Powerpoint : Gagas Media, Jakarta.

Trianto. 2010. Mendesain Model Pembelajaran Inovatif-Progresif: Implementasinya pada Kurikulum Tingkat Satuan Pendidikan(KTSP). Jakarta : Rencana Prenada Media Group. 